\title{
URBAN REGENERATION OF INDUSTRIAL SITES: BETWEEN HERITAGE PRESERVATION AND GENTRIFICATION
}

\author{
RAFAELA SIMONATO CITRON \\ University of São Paulo, Brazil
}

\begin{abstract}
This work is part of $\mathrm{PhD}$ research that addresses two recurrent problems in large Brazilian cities: the risk of demolition of important industrial buildings - due to several factors, such as the advanced state of degradation given the lack of use, the lack of recognition of this heritage in the country and the pressure of the real estate market, increasingly interested in the land these sites occupy - and the great demand for housing in central areas. The two themes - the preservation of industrial heritage and social housing in central areas - are rarely addressed together. Internationally, especially in the UK, the reuse of industrial heritage for residential use is quite common and has been going on since the first factories were closed with deindustrialisation and consequent industrial deconcentration, leading to the abandonment of several industrial sites in areas with complete urban infrastructure. Although successful in terms of preserving industrial heritage, since they enabled this heritage to be kept in the urban landscape, the adaptive reuse projects and the site's urban regeneration usually result in the gentrification of the regenerated area through projects carried out via a partnership between the public and the private sector that, even by offering a portion of onsite affordable housing, fail to serve the local community, let alone solve the country's housing problem. This article will show as a case study the Royal Arsenal district, in the south-east of the docks in London, with the aim of demonstrating how the urban regeneration, while preserving industrial heritage, divided the neighbourhood and contributes to its gentrification.
\end{abstract}

Keywords: urban regeneration, industrial heritage, gentrification, conservation, heritage.

\section{INTRODUCTION}

The United Kingdom, as well as being a pioneer in the industrialization process, was one of the first nations to suffer from deindustrialisation and the consequent industrial deconcentration. As Stratton [1] explains, the industrial sites demanded the proximity to the city centre, where the main services were, to the river, through which much of the freight transport took place and with the working-class dwellings, since most of the worker used to walk to work. The evolution of the means of transportation and, more recently, environmental concern has caused industries to be removed from the central areas.

In the United Kingdom, the reuse of industrial heritage is a well-established practice, in particular its adaptive reuse for housing purposes. With a growing demand for new housing, the City of London encourages the practice and, since 2017, industrial buildings (small and unlisted) can be converted to residential use without the need for planning permission, in a scheme called Permitted Development Rights. However, while the practice of reuse for residential purposes has enabled the conservation and valorisation of this heritage, on the other hand urban regeneration projects have resulted in elitist spaces, which end up gentrifying areas previously predominantly occupied by the working class. With several urban regeneration projects taking place at the same time, as in Battersea and Elephant and Castle, for example, London in going through a widespread gentrification. According to the government's official list, there were 246,575 families on the housing waiting list in the City of London in 2020. 
In addition to social problems, the heritage issue itself is also questioned. Industrial heritage is seen by many authors as a different kind of heritage, or at least with some characteristics that differentiate them from other heritage buildings. One of the reasons is the proximity that this heritage still has to the communities that created them. As deindustrialization is still a recent event, many worker's families still live in the vicinity of the former industrial sites. The feeling of belonging of the community with these sites bring to the industrial heritage an intangible dimension that has been little explored and preserved in the urban regeneration projects of industrial sites. Cossons [2] talks about these values attributed to industrial heritage, which go far beyond the documentary and material value of the buildings themselves and argues that the preservation of this heritage from the arguments and values attributed to other heritage buildings is often not well received by the community. According to the author, industrial heritage brings challenges that are not found in other sectors of heritage, such as the need to recover socially and economically these areas that are affected by unemployment and economic collapse [2]. It is on top of the argument of economic and social recovery that urban regeneration projects arise. In Architectural Design's special edition on urban regeneration, Littlefield [3] explains:

\begin{abstract}
"The term regeneration is most usefully invoked as part of an attempt to reverse economic decline and social deprivation, a set of actions to restart the process of generating wealth and providing inhabitants with viable social and economic choices. Property development, or 'urban renewal', might well be the catalyst for these things, but there is always the danger that it becomes a placebo" [3]
\end{abstract}

When mentioning market-led urban regenerations, the author talks about the various transformations that took place in east London driven by the Olympics and quotes Susan Betty, who in 2003 said that the danger was not that these projects would cause the removals of former residents, but that they would simply ignore the communities [3]. This is the case of Woolwich and the regeneration of the Royal Arsenal, a military industrial site who's regeneration started in the 2000s and comprised of the reuse of the old warehouses for residential purposes, the construction of new residential buildings as well as new cultural uses, shops and a new public transport link, the Crossrail, which will connect Royal Arsenal to Canary Wharf and the City, London's two main financial districts. Because of this, the district has attracted and continues to attract middle-class young workers from other areas of London. Thus, today the District of Woolwich is divided into two very distinct parts: the regenerated part and the rest of Woolwich.

\title{
2 URBAN REGENERATION AND INDUSTRIAL HERITAGE IN THE UK
}

As already mentioned, the United Kingdom was one of the first nations to industrialise, to suffer from the consequences of deindustrialisation in the post-War period and, consequently, also pioneers in initiating the process of economic reconversion of abandoned industrial sites. The first interventions in these sites, in the post-war period, comprised of the demolition of various sets of work class housing, under the influence of the Garden City movement. Couch et al. [4] explains that these interventions became known in the United States and the United Kingdom as Urban Renewal, which can be understood as physical interventions for the redevelopment of the affected area, also known as slum clearance. Urban renewal occurred as the same time as post-war reconstruction until the 1960s, when it became clear that it was 
needed much more than just interventions in the physical environment, but instead it was necessary to socially and economically recover the old industrial areas [4].

The example came from the United States, which in the mid-1960s regenerated several former ports, such as the Port of Baltimore, which began its regeneration process in 1962 with a public investment of $\$ 180$ million. Although the reuse and conservation of industrial heritage were also present, in the United States the construction of new buildings was predominant over adaptive reuse, as well as new uses focused on tourism, such as shopping malls and marinas. In other American ports, mixed-use projects - offices, housing for the middle class and leisure - became a formula that would later be exported to Europe, Africa and Asia [2].

With regards to industrial heritage, until the 1960s, even though some buildings had already been included in the list of buildings to be preserved, there was not yet a national policy for preserving industrial heritage. The destruction of the arch on the main façade of Euston station in London in 1963, is known as a symbol of the Industrial Revolution, causing great pressure from the public and led the country to conduct a national survey of sites to be protected - Industrial Monuments Survey (IMS) [5].

Between 1963 and 1981, more than 4,000 sites were inventoried and 2,325 were listed as sites worthy of preservation. With the creation of English Heritage in 1984, the Monument Protection Program was created, which evaluated 5,000 more sites and buildings, recommended more than 1,000 for the designation of Ancient Monument and 350 candidates were listed by the end of the program in 2004 [5]. Today, there are more than 30,000 industrial buildings of interest for preservation in England, 4\% of which are listed as Grade I, the highest level of listing in the country.

Until the 1970s, most investments in urban regeneration projects came from the government [6]. The Urban Programme, created in 1968, distributed funds to municipalities to invest in social programmes, focusing on solving poverty problems in economically decaying areas. Over time, it became clear that the complexity and challenges of regenerating an area in social and economic decline required the participation of more actors in both the design and the delivery of demarcated areas. In the 1980s, with the arrival of Margaret Thatcher in the power in the United Kingdom and President Reagan in the United States, the state's welfare policies were heavily criticized, and state intervention came to be seen as a hindrance to economic development. Thus, in the 1980s there was a change in planning policies and, from then, urban regeneration projects were mainly led by the private sector [6]. This model remains present to this day and urban regeneration projects led by the housing market are called property-led regeneration in the UK.

These projects were made possible through the creation of Urban Development Corporations (UDC), entities chosen by the government that had the task of creating attractions to the private sector to bring investments to specific areas. From 1981 to 1993, the UDC regenerated 13 central areas in the United Kingdom, including the well-known London Docklands. The UDC received more government funding than the previous program, the Urban Programme, where there was no private sector participation [7]. The idea that marketled regeneration was the solution to the problems of urban degradation was also popular among municipalities in the late 1980s. Property-led regeneration became the formula to regenerate central areas without much justification or explanation and the relationship between interventions and the improvement of economic and social conditions of the communities where there was intervention were very little studied [7].

As pointed out by the author [7], urban regeneration projects led by the real estate market were not addressing the urban and social problems facing the country. The expected trickledown did not happen and, by the power given to the UDC, communities and municipalities 
were not being heard, just as poverty and social problems were not on the agenda of urban regeneration programs [6].

Thus, from 1991 a new program is implemented in government, where municipalities could apply to receive government funds to direct the regeneration of degraded urban areas: The City Challenge. Specific municipalities were invited by the government to submit applications for the program, many of them involving former industrial areas in decline [8]. The regenerations that occurred as part of this program continued to take place from partnerships with the private sector but led by local government and with popular consultation. This programme can be considered the first British experience where there was integration between the interests of the private sector and local communities [6]. However, the success of the program is also questionable from the social point of view.

In 2000, urban regeneration projects focused again on the real estate market, when the government published the Planning Guidance Note 3, where it disclosed urban planning and housing strategies. In this note, the government set a target of $60 \%$ of new housing being in brownfields, through the adaptive reuse of existing buildings [9]. This measure further encouraged urban regenerations led by the real estate market, through the reuse of old buildings for residential purposes.

Questions are being made whether communities have been heard and actually contribute to decision-making or whether popular consultation is just a box to be ticked, with communities being manipulated to legitimize urban regenerations, with little or no decisionmaking power in relation to what will be delivered by public-private partnerships in their neighbourhoods [6].

\section{ROYAL ARSENAL, WOOLWICH}

\subsection{Brief contextualization}

Woolwich is a district in south-east London and is part of the Borough of Greenwich. With a long history, with archaeological records indicating occupation since the Iron Age era, Woolwich housed for 300 years the largest royal artillery factory - Royal Arsenal. Since 1565 , the factory has produced and ammunition and had its heyday during the first world war, being the largest source of British ammunition used in the conflict. During this period, Royal Arsenal employed 80,000 people [10].

Masters [10] - who was born in the neighbourhood and saw Royal Arsenal at its peak when he was 6 years old and lived with his father, Superintendent of the Factories of Arms and Transport, in one of the buildings of the Royal Arsenal - points in his book to the fact that few people, even local residents, know the history of Royal Arsenal and that the neighbourhood ends up being better known due to the football team Arsenal F.C., which emerged on site at the end of the 19th century, formed by factory workers. The author reports that after its peak between 1915 and 1920, factories began to be dispersed in the 1930s, with the realization that future conflicts would happen through the air, making the concentration of ammunition factories in the same place unsafe. With this, until the beginning of the Second World War, the number of workers went from 80,000 to 30,000. In fact, the site was bombed a few times during the second war, leaving 103 workers dead and another 770 wounded [10].

The site began to decline in the $1950 \mathrm{~s}$, when ammunition production was transferred to private industries. The Ministry of Royal Defence occupied for some years some of the buildings until, in 1967, the Royal Ordnance Factory was officially decommissioned. Of the 1,300 hectares that belonged to the artillery complex during its years of operation, there were only 76 hectares left, which were still occupied by the Ministry of Defence (MoD) until 1994. 
At the time of the publication of Roy Masters' book in 1995, the area was unoccupied and "awaiting redevelopment" [10]. According to the author, with the announcement that MOD would leave the site, some residents came together and created the Royal Arsenal Museum Advisory Group (RAMAG), with the aim of creating a Heritage Centre with several museums in some of the most important buildings in the neighbourhoods that the history of the site would not be lost. The author also comments, at the end of his book, that the group had already presented the proposal to the Greenwich Council, which encouraged them by saying that "the proposal was very aligned with the municipality's strategy, which aims to raise public and private money to promote jobs, housing and leisure on the 7 miles of land along the river" [10].

In 1992, Greenwich entered the competition to participate in the City Challenge, a government program that, unlike the urban regenerations of the 1980s, was led by the municipalities and allowed greater community participation and greater control under interventions by the private sector. In a video available online, submitted to the government as part of the material needed to join the competition, it is clear the willingness of the community to integrate Royal Arsenal with the rest of Woolwich.

Unfortunately, Greenwich did not win the City Challenge but its urban regeneration began a few years later. The SHARP (Sustainable Historic Arsenal Regeneration Partnership) project, funded by the European Union and led by English Heritage, published an analysis of intervention projects in former military areas, with case studies from England, Malta, Spain and Estonia with the aim of devise sustainable urban regeneration strategies based on the appreciation of industrial heritage. The English case analysed in the publication is the Royal Arsenal, which is therefore the largest source of information on the case.

\subsection{The urban regeneration of Royal Arsenal}

In 199731 hectares equivalent to the part where the listed buildings were, were sold to English Partnerships (EP), at the time the urban regeneration agency of England, for $£ 1$ (one pound) [11]. At the time of the sale, 22 buildings had already been listed and the area had been demarcated as a Conservation Area in 1981. According to the author, in the mid-1990s there were more than 60 buildings on the site, with years of construction between 1690 and 1970 , most of them in good condition. This number decreased considerably by the end of the 1990s (Fig. 1).
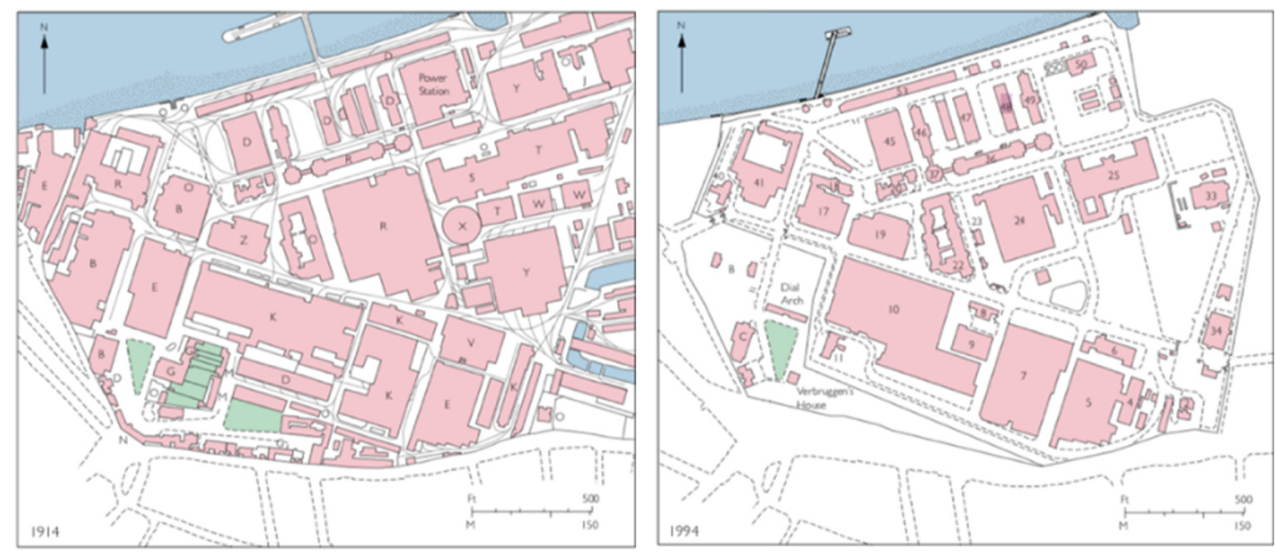

Figure 1: Royal Arsenal, compared between 1914 and 1994. 
As already seen, in 1993, the Greenwich Waterfront Development Partnership had already included Royal Arsenal in its masterplan, with the strategy of regenerating the neighbourhood through the idea of diversified economy, given that the neighbourhood, because of the closure of factories, had an unemployment of $17 \%$ [11]. The urban regeneration strategy of the neighbourhood was based mainly on its heritage value and economic potential, with the objective of creating a living neighbourhood, mixing new and old buildings and uses such as housing, culture, work and leisure.

The year after the Royal Arsenal's land purchase in 1998, the English Partnership began to draw up a plan for urban regeneration, where the main objective was to promote private investment. One of the first strategies was to trace a zoning dividing the neighbourhood into 4 zones (Fig. 2): housing, along the River Thames; shops and services, in the eastern portion, near the highway and the rest of the Woolwich district; cultural uses near the pier on the main street of the neighbourhood (street number 1) and, finally, leisure activities in the east.

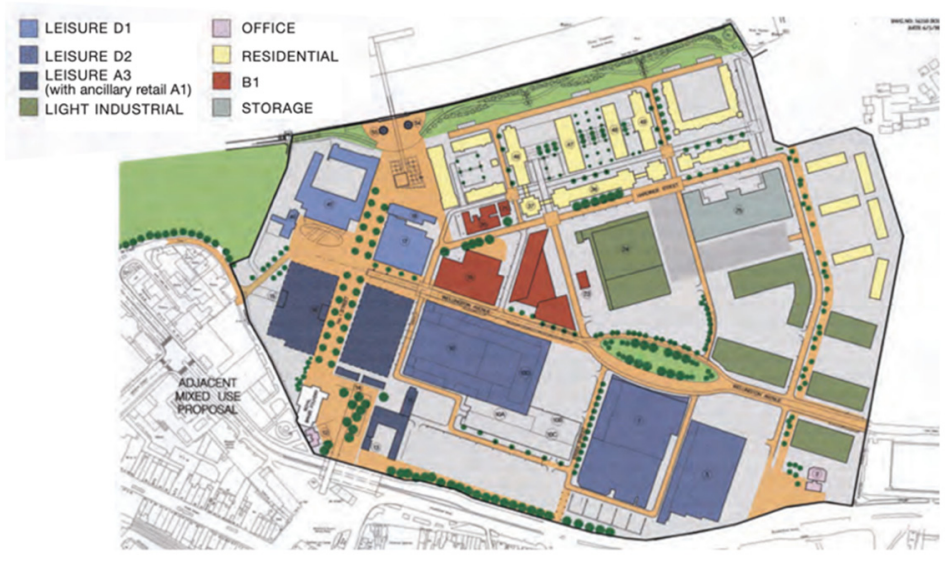

Figure 2: Masterplan 1998.

The masterplan developed by Llewelyn Davis Yeang was approved by the municipality of Greenwich in the form of an Outline Application, which means that the project delivered for approval was not detailed but rather a plan that made clear the intentions and especially respect for architectural heritage to be preserved but allowed flexibility for changes to occur over the years [11]. Stevenson [11] judges this decision as correct, since it was not possible at that time, in 1998, to establish with certainty what use each of the buildings would have, since there was not yet at stake the partner of the private sector, which entered two years later. The most important buildings, such as the Grand Store, a complex of warehouses built between 1803 and 1813 were preserved externally almost in its entirety, while its interior underwent further modifications. Most of the buildings had free plants and had to be partitioned to receive residential use. In the initial approved plan, building 22 - former Administrative Centre had been demarcated as possible demolition and would give way to a new office building (use B1), since it was not listed. However, later in the regeneration process it was eventually preserved and reused thanks to the insertion of three other floors.

In the year 2000, Berkeley Homes Ltd. was selected as the housing developer, who would be the private sector actor to develop the adaptive reuse projects of the first warehouses, transforming them into both private and affordable housing. 
Since the publication of the Town and Country Planning Act in 1990, municipalities have defined a percentage of dwellings that must be delivered as affordable housing. This policy, defined by Section 106 of the legislation, is the biggest guarantee yet of affordable housing, as the UK no longer produces Council Housing, built in large numbers under the Welfare State, especially in the post-war period until the late 1970s. In Greenwich, the requirement is that new developments, whether in new construction or in reuse of old buildings, deliver a minimum of $35 \%$ in affordable mode. Of these, one third refers to social rent, one third as shared ownership and the remaining third is for keyworkers. These are usually run by nonprofit housing cooperatives.

According to Berkeley Homes [12], the regeneration programme received an initial $£ 43 \mathrm{~m}$ investment from the Ministry of Defence for the decontamination of the former industrial site. Berkeley Homes initially won the competition with a $£ 150$ million project for the adaptive reuse of four listed buildings and to turn them into 700 homes, $35 \%$ of them affordable and the rest at market price. In 2003, two years before the scheduled completion of the works, the company acquired some other buildings and obtained approval to turn them into an additional 550 apartments and, just a year later, bought the rest of the EP site (western portion of the neighbourhood, which would initially be destined for an urban park) for the installation of bars and shops, in addition to 2,500 more apartments and the creation of the new Cross Rail station [12]. Thus, thanks to the flexibility of the masterplan initially approved, in 2005 a revised masterplan, this time prepared by the office Allies and Morrison.

The plan was submitted at least twice for approval, once in 2009 (Fig. 3) and another in 2013. At this time, much of the old buildings had already been converted into housing and these masterplan revisions refer to the western portion of the neighbourhood, acquired by Berkeley Homes in 2004. As already mentioned, this area had been demarcated in the 1998 masterplan as a leisure area and was planned the construction of a park, whose area was drastically reduced in the submissions of 2009 and 2013.
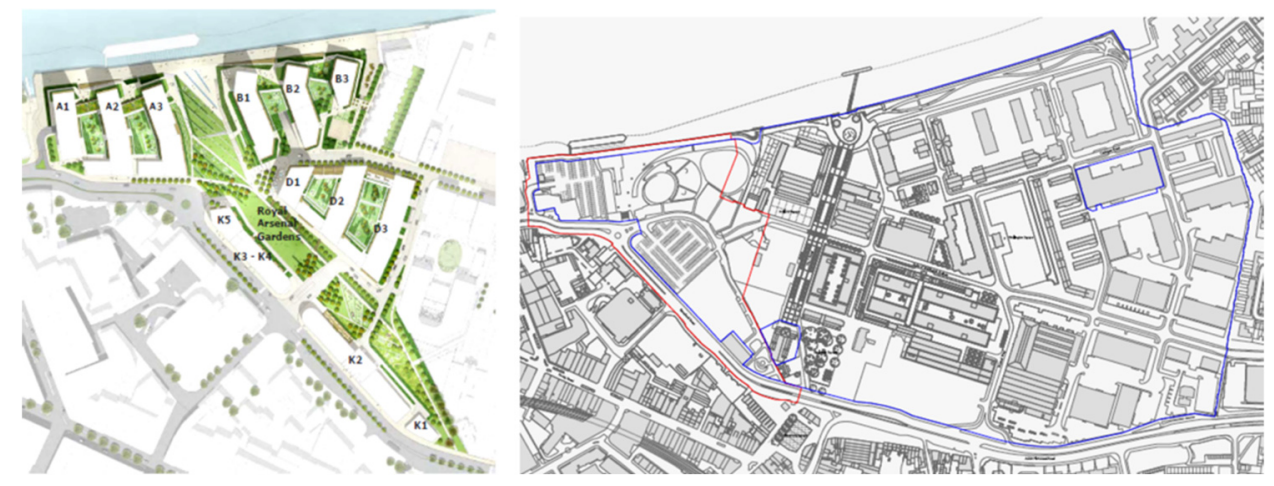

Figure 3: Additional site included in the 2006 masterplan.

In addition to the loss of area initially destined for leisure, another important change in the plan was related to the parcel destined to affordable housing. The first masterplan had promised that $35 \%$ of the total apartments would be destined to affordable housing divided into three modalities, as previously mentioned: social renting, shared ownership and key worker housing. In reviewing the plan, this percentage was reduced to $25 \%$, with the justification that Berkeley Homes was investing in the construction of the Cross Rail station. 
The municipality accepted the justification, adding that the number of dwellings had increased in absolute values, despite the decrease in percentage.

It is noteworthy that the values of apartments rented or sold at affordable prices are based on market values. According to the Berkeley Homes website, apartments in the new developments range from $£ 470,000$ (apartments with connecting bedroom and living room) to $£ 1,050,000.00$ ( 2 or 3 bedroom apartments). Housing cooperatives sell the apartments at $25 \%$ of the market value in the Shared Ownership scheme, where the buyer owns this percentage and pays rent for the remainder of the amount they did not purchase, around $£ 600$ per month. Families with incomes of up to $£ 90,000$ a year can buy in this mobility. The social housing modality is the only one that is really affordable for the low-income population, with rents around $£ 106$ (if rented directly from the council) or $£ 122$ (if rented from housing cooperatives).

With regard to cultural uses, which Roy Masters hoped would be included in the plan in 1995, in fact in 2001, in the first year of regeneration, the Firepower Museum was opened and operated in the neighbourhood until 2016, when it was closed with the promise of reopening it in Salisbury Plain, near Stonehenge, $150 \mathrm{~km}$ from the Royal Arsenal district, where the sniper training used to take place. On the site of the museum and in four other listed buildings will be held the last stage of the regeneration project, which will be inaugurated in spring 2021: Woolwich Works, a cultural centre with space for exhibitions, shows and cultural activities in general, as well as cafes and bars.

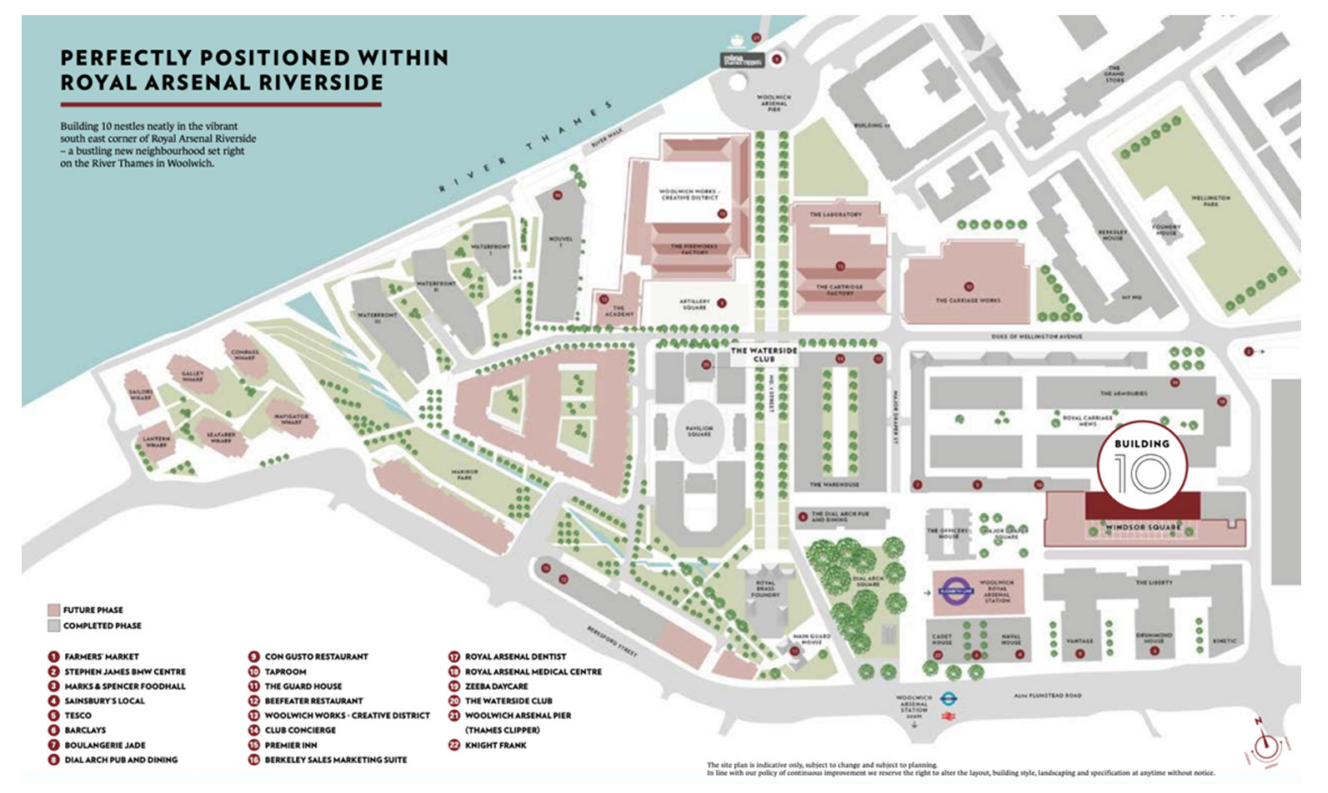

Figure 4: Updated zoning of the neighbourhood, building 10 dissemination material.

\subsection{Woolwich and gentrification}

In September 2014, Berkeley Homes interviewed 226 residents of the neighbourhood, which at that time corresponded to $11 \%$ of the inhabitants. Among these, $67 \%$ were residents in the private housing modality (private owners or tenants) and $32 \%$ in the affordable modality, 
with the intention of representing the real percentage of the different ways of living in the neighbourhood. The result of this survey indicates a community happy with their neighbourhood, where $93 \%$ of residents consider themselves happy with the place where they live and $75 \%$ think that the place where they live contribute so much to the sense of identity, the latter increasing considerably among the inhabitants of affordable units $(90 \%)$. The research highlights that people in Royal Arsenal feel safe in the neighbourhood compared to the rest of Woolwich and that regeneration has changed the reputation of the neighbourhood [12].

The survey would have shown very different data if it had involved residents of the Woolwich neighbourhood as a whole, not just the residents of the regenerated part who are mostly people from other parts of London, attracted by the new developments and the good connection of the neighbourhood with the rest of London. Still, research with residents of Royal Arsenal raised the issue of visible separation between the two parties. In fact, what you see today are two distinct neighbourhoods. The wall and the highway are two physical barriers that symbolize a social separation between the new residents of the regenerated neighbourhood and the residents of Woolwich from the process of urban regeneration presented.

In March 2020, a group of students from University City London (UCL) conducted interviews with residents of the Royal Arsenal and with the rest of Woolwich. The results, not yet published, show this disconnect between the regenerated part and the rest of the neighbourhood. Royal Arsenal residents generally say they don't like the rest of the neighbourhood and avoid going there because they don't feel safe, while Woolwich Arsenal residents say they don't visit Royal Arsenal because they don't feel welcome, as it's a place for wealthier people.

Twenty years have passed since the start of the Royal Arsenal's urban regeneration process and now Woolwich residents fear that the neighbourhood's next stages of urban regeneration will cause even more gentrification as well as displacement, something that had not happened in the regeneration of the Royal Arsenal, as there were no residences within the industrial site. Among the new projects planned for the neighbourhood, two stand out:

1. Spray Street Quarter: the project, carried out from the partnership between the Royal Borough of Greenwich (municipality) and St. Modwen Companies, Notting Hill Housing, signed in 2016, provided for the demolition of a block, south of the highway that divides Woolwich and Royal Arsenal (Beresford Street) and east of the old portal. The project was barred in 2018, when the old market located on the block was listed. The project is under review.

2. Woolwich Estates Regeneration: Second site of the Royal Borough of Greenwich, the project consists of the demolition and re-development of 3 housing estates of the neighbourhood. In all, 1,064 social housing apartments will be demolished to make way for new 1,500 units, of which $35 \%$ will be affordable, among which only a third will be of similar values to social rent, which previously represented the totality of the apartments.

The Speak Out Woolwich group, made up of neighbourhood residents and shopkeepers, is a resistance group against the gentrification of Woolwich. The main demand of the group is for the fulfilment of the minimum of social housing and the maintenance of the identity of the neighbourhood, nowadays mainly formed by local commerce, which runs the risk of being gradually expelled to make way for the stores of networks, attending to a public of higher standard, as the one that currently lives in the Royal Arsenal. 
In September 2002, Woolwich received a new government fund to regenerate the main avenue in the centre of the neighbourhood, Powis Street (Fig. 5), again focusing on historical heritage and with the same goal of promoting the economic and social improvement of the neighbourhood.

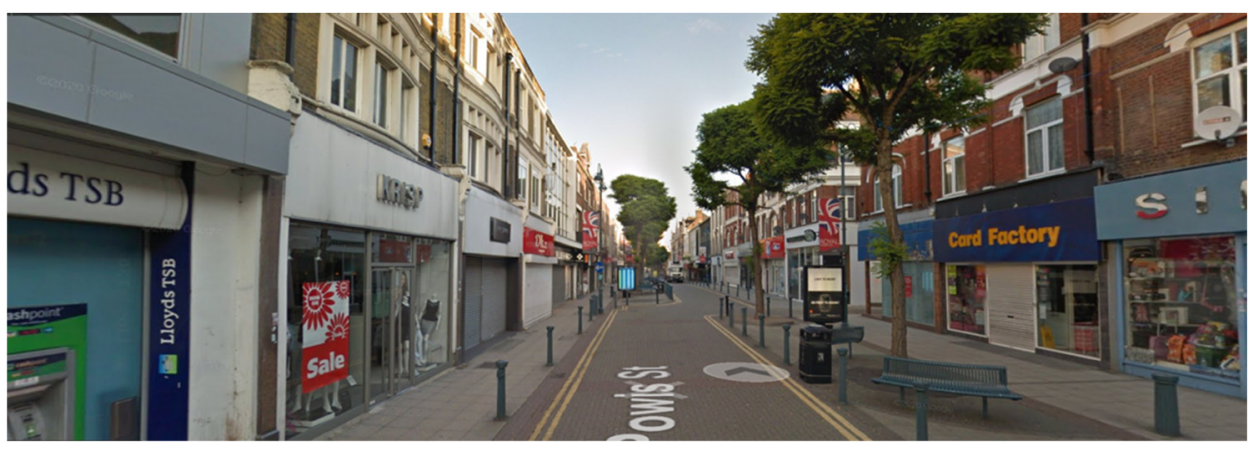

Figure 5: Powis Street.

\section{FINAL CONSIDERATIONS}

It is considered that the example presented, Royal Arsenal, is a good example with regard to the preservation of industrial heritage. Since the site was acquired by the EP to start the process of urban regeneration, most of the buildings have been preserved. The demolitions had taken place years earlier, after the closure of the factories. The listed buildings underwent few external changes and even unlisted buildings were saved, but with major interventions, such as building 22 , where three new floors were added at the top. The new buildings within the conservation area respect the importance of historic buildings, both for the height and design and design used and contribute to the valorisation of industrial heritage.

However, especially since the 1980 s, it is recognized that the preservation of heritage does not only concern the physical preservation and materials of buildings and as already seen, when it comes to industrial heritage are not always the most important values to be preserved. The relationship of these sites with their communities, either due to the number of years in which the factories were in operation or because the impact that their closure caused is very strong. In the case of the Royal Arsenal, one can see in the speech of people interested in regenerating the area how much there was an expectation that the site would be opened and connected with the rest of the neighbourhood, so that all people would use that space so privileged by the proximity to the river and its history, which is the history of Woolwich. Royal Arsenal is now the noble part of Woolwich and there is no longer a sense of belonging between the community of Woolwich and its former industrial site. Residents of Woolwich today are battling the gentrification of the neighbourhood that has been going on since the urban regeneration of the Royal Arsenal.

From this case study, there is the possibility of thinking about alternatives so that old industrial areas can be regenerated, preserving their assets, generating employment and housing, but that can also meet the needs of the community that is generally strongly related to industrial sites. It is understood the need for private sector involvement to bring investment that the state often lacks, but the participation of the government is critical to ensure that the project delivered meets the needs of local communities. With the example presented, it is clear the need for legislation that requires counterparts from the private sector, but this cannot 
be the only way to guarantee housing with affordable values for the population, since very low percentage of social housing ends up not allowing a true mix of different social classes.

The next phases of this research intend to study the policies of housing, planning and protection of historical heritage in Brazil and especially in the city of São Paulo to verify the barriers and opportunities in the viability of projects to reuse industrial heritage for social housing.

\section{REFERENCES}

[1] Stratton, M. (ed.), Industrial Buildings: Conservation and Regeneration, Taylor \& Francis, 2003.

[2] Cossons, N., Why preserve the industrial heritage. Industrial Heritage Re-tooled: The TICCIH Guide to Industrial Heritage Conservation, pp. 6-16, 2012.

[3] Littlefield, D., (Re) generation: Place, memory, identity. Architectural Design, 82(1), pp. 8-13, 2012.

[4] Couch, C., Sykes O. \& Börstinghaus, W., Thirty years of urban regeneration in Britain, Germany and France: The importance of context and path dependency. Progress in Planning, 75(1), pp. 1-52, 2011.

[5] Falconer, K., Legal protection. Industrial Heritage Re-tooled: The TICCIH Guide to Industrial Heritage Conservation. Part III: Realising the Potential, p. 94, 2012.

[6] Carpenter, J., Decision-making in regeneration practice. Architectural Regeneration, pp. 47-60, 2020.

[7] Turok, I., Property-led urban regeneration: Panacea or placebo? Environment and Planning A, 24(3), pp. 361-379, 1992.

[8] Bonshek, J., The 1991 city challenge bids: A review article. The Town Planning Review, 63(4), pp. 435-445, 1992.

[9] Jones, P. \& James, E., Urban Regeneration in the UK: Boom, Bust and Recovery, Sage, 2013.

[10] Masters, R., The Royal Arsenal, Alan Turner: Woolwich, p. 1005.

[11] Stevenson, M., Regeneration through Heritage: Understanding the Development Potential of Historic European Arsenals, English Library: Swindon, 2016.

[12] Berkeley Homes, Royal Arsenal Riverside: A case study about transport and placemaking. http://www.berkeleygroup.co.uk/media/pdf/n/b/Berkeley-royal-arsenalriverside-case-study.pdf. 